\title{
PERFORMANCE OF AIR INDUCTION SPRAY NOZZLE MODELS UNDER DIFFERENT OPERATING CONDITIONS
}

\author{
João P. A. R. da Cunha ${ }^{1 *}$, Jorge A. L. França ${ }^{1}$, Cleyton B. de Alvarenga ${ }^{2}$, \\ Guilherme S. Alves ${ }^{3}$, Ulisses R. Antuniassi ${ }^{4}$
}

\author{
${ }^{1 *}$ Corresponding author. Federal University of Uberlândia/ Uberlândia - MG, Brazil \\ E-mail: jpcunha@ufu.br| ORCID ID: https://orcid.org/0000-0001-8872-3366
}

\begin{abstract}
KEYWORDS
spray tip, droplet spectrum, sprayer, application technology.
\end{abstract}

\begin{abstract}
For the successful application of phytosanitary products, it is essential to understand the spraying process well. The present work aims to evaluate the spectrum and speed of the droplets produced by different spray nozzle models with air induction, working under different operating conditions. The experiment was conducted using an entirely randomized design with five repetitions in a $3 \times 3 \times 3$ factor scheme that incorporates three nozzle models (ADIA, AIXR, and GA), three nominal flows $(0.76,1.14$, and 1.51 $\left.\mathrm{L} \mathrm{min}^{-1}\right)$, and three operating pressures $(200,300$, and $400 \mathrm{kPa})$. The spectrum and speed of the droplets were determined directly using a real-time droplet analyzer based on highresolution image analysis. The spray nozzle model interfered with the results. The ADIA promoted $\mathrm{Dv}_{0.5}$ (VMD) higher than AIXR and GA, reaching differences of up to $90 \%$. The increase in pressure promoted a reduction in the droplet size; however, there was no well-defined behavior for the relationship between the flow rate and droplet size. The ADIA and AIXR gave rise to greater uniformity of the droplets in most of the evaluated conditions. The increase in pressure promoted an increase in the speed of the droplets. However, the effect of the nozzle model on this parameter was dependent on the flow.
\end{abstract}

\section{INTRODUCTION}

The drift of phytosanitary products is a major practical problem in contemporary agriculture. Several factors contribute to its occurrence, including the weather conditions during application and the size of the droplets used. The first factor cannot be controlled, but the second can be. Droplets with a diameter of less than $150 \mu \mathrm{m}$ are often the most subject to wind-driven drag (Ferguson et al., 2016). While larger droplets are safer from an environmental point of view, they promote less target coverage, which may interfere with the effectiveness of the treatment (Ferguson et al., 2015). Therefore, it is essential to know the spraying process well.

The spectrum of droplets produced during spraying depends on factors such as working pressure, physical and chemical properties of the spray solution, and the spray nozzle (Butts et al., 2019a). Air induction nozzles are the most commonly used for drift reduction (Garcerá et al., 2017). Although these nozzles were the last to be launched in the market, a wide range of models are already available to the farmer. However, most users are unaware of the differences between the different models, particularly because scientific literature itself is lacking in comparative information, especially in the case of recently released nozzle designs.

Air induction tips incorporate a hole that, as per the Venturi concept, allows air to enter (Butts et al., 2019b). In the mixing chamber, air and liquid are combined by turbulence, which is then attenuated in the stabilization zone. The homogeneous mixture of air and liquid then reaches a conventional tip and exits to the outside. The liquid flow and droplet size also depend on the working pressure and size of the restrictor orifice. However, the combination of the restrictor, air, and conventional final

\footnotetext{
${ }^{1}$ Federal University of Uberlândia/ Uberlândia - MG, Brazil

${ }^{2}$ Federal University of Uberlândia/ Monte Carmelo - MG, Brazil

${ }^{3}$ University of Nebraska-Lincoln/ North Platte - NE, USA

${ }^{4}$ São Paulo State University/ Botucatu - SP, Brazil
} 
orifice leads much complexity in the behavior of the droplets, and makes the selection of the nozzle difficult. Butts et al. (2019b) state that these nozzles present great variation in the spray pattern, especially at low working pressures, when compared to the nozzles without air induction.

It is certain that air induction nozzles reduce drift (Bueno et al., 2017); however, the extent to which each model, with its different designs, interferes with the droplet spectrum and consequently, the reduction in drift losses, is unknown. Although they all have a Venturi system for incorporating air in the droplets, the different designs can confer the spectrum and droplet speeds characteristic to each model, which can result not only in the reduction of drift, but also in the spray deposition on the desired target. Therefore, knowing these differences is fundamental for the success of a phytosanitary application (Ferguson et al., 2015).

Thus, the present work aimed to evaluate the spectrum and speed of the droplets produced by different spray nozzle models with air induction, working under different operating conditions.

\section{MATERIAL AND METHODS}

The experiment was carried out at the Laboratory of Spraying Machines of the School of Agronomic Sciences of the Universidade Estadual Paulista - FCA/UNESP, in Botucatu - SP.

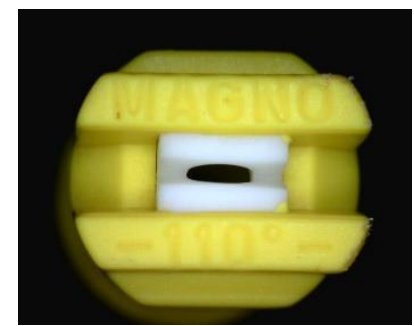

ADIA (0.76 $\left.\mathrm{Lmin}^{-1}\right)$

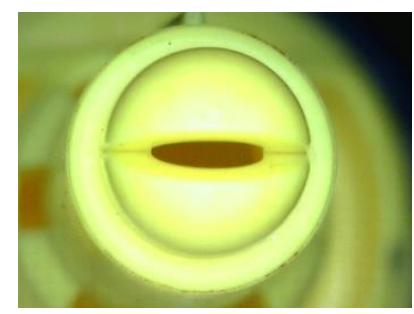

GA $\left(0.76 \mathrm{Lmin}^{-1}\right)$

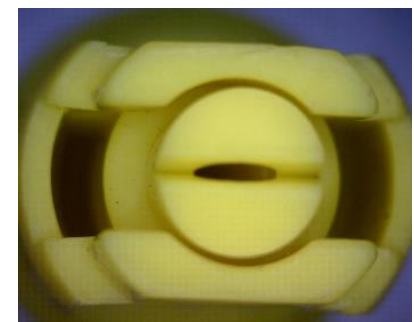

AIXR (0.76 $\left.\mathrm{Lmin}^{-1}\right)$

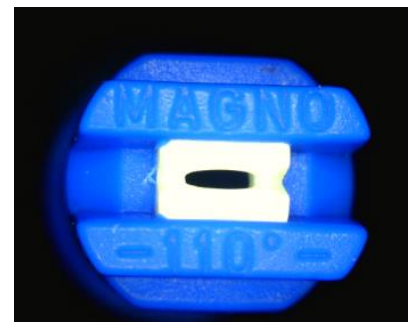

ADIA (1.14 $\left.\mathrm{Lmin}^{-1}\right)$

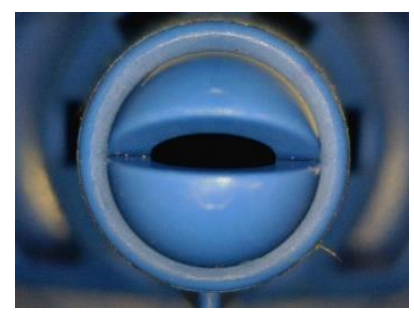

GA $\left(1.14 \mathrm{Lmin}^{-1}\right)$

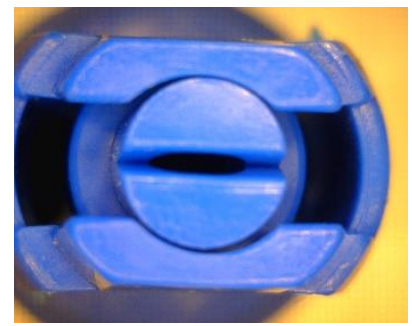

$\operatorname{AIXR}\left(1.14 \mathrm{Lmin}^{-1}\right)$
The spectrum and speed of droplets generated by different air- induction spray nozzle models were evaluated under different operating conditions. Three flat fan spray nozzles having an opening angle of $110^{\circ}$ were used, namely, ADIA (Magnojet ${ }^{\circledR}$, Ibaiti, Brazil), AIXR (Teejet ${ }^{\circ}$, Wheaton, USA), and GA (Hypro®, Delavan, USA). The ADIA were made using ceramic cores, presenting an elongated profile with four air intakes, two on each side. The AIXR were made of polymer, with a more compact profile, presenting two air intakes on opposite sides. The GA were fabricated using polyacetal, also with two air inlets on opposite sides.

The experiment was conducted using an entirely randomized design, with five repetitions, in a $3 \times 3 \times 3$ factor scheme (three spray nozzle models, three flow rates, and three operating pressures). Each repetition was associated with one spray tip, i.e. five different spray tips were used to assemble the five repetitions, but using the same model. Nozzle with nominal flow rates of 0.76 (11002), 1.14 (11003), and 1.51 (11004) $\mathrm{L} \mathrm{min}^{-1}$ were evaluated at pressures of 200, 300 and $400 \mathrm{kPa}$.

The exit holes of the nozzle were measured in order to better characterize them (Figure 1). The length, width, and area of the hole were measured using a digital microscope (AM413ZT, Dino-Lite) and the software provided by the manufacturer Dino Capture (version 2.0).

FIGURE 1. Exit holes of the evaluated nozzles. 
All the tests were performed with the same type of spray solution. To reduce the surface tension to levels closer to those employed in the field, the adjuvant Agral from the manufacturer Syngenta was added, which is an adhesive spreader having Nonylphenoxy polyethoxy ethanol as the active ingredient. The surface tension of the water used at a temperature of $25^{\circ} \mathrm{C}$, was $72 \mathrm{mN} \mathrm{m}^{-1}$, and after the addition of adjuvant at a concentration of $0.05 \% \mathrm{v} \mathrm{v}^{-1}$, it was reduced to $32 \mathrm{mN} \mathrm{m}^{-1}$.

Spraying was evaluated by considering the spectrum and speed of droplets produced by the nozzles under different operating conditions. The following parameters were obtained: $\mathrm{Dv}_{0.1}$ (droplet diameter such that $10 \%$ of the volume of liquid sprayed is made up of droplets smaller than that value), $\mathrm{Dv}_{0.5}$ (droplet diameter such that $50 \%$ of the volume of liquid sprayed is made up of droplets smaller than that value, also known as the volume median diameter VMD), $\mathrm{Dv}_{0.9}$ (droplet diameter such that $90 \%$ of the volume of liquid sprayed is made up of droplets smaller than that value), droplet velocity, and relative amplitude (RA). The RA was determined using the following equation:

$$
\mathrm{RA}=\frac{\mathrm{Dv}_{0.9}-\mathrm{Dv}_{0.1}}{\operatorname{Dv}_{0.5}}
$$

The measurements were performed directly using a real-time droplet analyzer based on high-resolution image analysis. A VisiSize portable P15 particle imager (Oxford Lasers, Imaging Division, Oxford, U.K.) was used. In this method, the characterization is performed in real time using the Visisize Particle Sizing software, developed by the equipment manufacturer itself. The system analyzes the droplet spectrum using a technique called Particle/Droplet Image Analysis (PDIA) (Carvalho et al., 2017). The system is capable of measuring droplets with diameters above 5 $\mu \mathrm{m}$. Besides measuring the particle diameter distribution, the equipment provides the speed of the particles in real time. To provide the average values of the spray parameters, the system was programmed to count ten thousand drops in each repetition.
Prior to each test, calibration of the particle analyzer was performed using a TeeJet ${ }^{\circ}$ spray tip, model XR8003, and water-only solution, which produces droplets with a VMD of $150 \mu \mathrm{m}$.

In determining the droplet spectrum, a spraying equipment was used, which was mounted in such a way that the entire sprayed jet passed transversely through the light beam of the analyzer, allowing the direct determination of the average droplet spectrum for each desired condition. The spray nozzle was located $50 \mathrm{~cm}$ above the optical beam.

The tests were performed in a controlled environment to minimize the effect of environmental conditions (air temperature below $28^{\circ} \mathrm{C}$, relative air humidity above $60 \%$, and no wind).

All the data obtained were first tested for the residue normality (Shapiro-Wilk and Kolmogorov-Smirnov), and for the variance homogeneity (Levene), both at 0.01 of the significance, with the SPSS program (version 20). In cases where the assumptions were not met, the data were transformed into $\sqrt{\mathrm{x}}$ and the analysis was repeated $\left(\mathrm{Dv}_{0.1}\right.$, $\mathrm{Dv}_{0.5}$ and $\left.\mathrm{Dv}_{0.9}\right)$.

In all the experiments, after the analysis of the assumptions, the data were subjected to analysis of variance by the statistical program SISVAR (version 5.3). When pertinent, the treatments were compared with each other by Tukey's test, at a significance of 0.05 .

\section{RESULTS AND DISCUSSION}

Table 1 shows the dimensions of the exit hole of the evaluated nozzles. It is noted that, even with equivalent flow rates, each model has its own characteristics that distinguish them from the others. The increase in flow occurs with an increase in area, which can be influenced by both the length and the width, as well as changes in the size of the droplets. The ADIA nozzle presented holes with a larger area, mainly due to the increase in length. The nozzle AIXR and GA presented an increase in flow based both on the increase in the length of the orifice, as well as the width.

TABLE 1. Dimensions of the exit hole of the evaluated nozzles.

\begin{tabular}{|c|c|c|c|c|}
\hline Nozzle & $\begin{array}{c}\text { Nominal flow rate } \\
\left.(\mathrm{L} \mathrm{min})^{-1}\right)\end{array}$ & $\begin{array}{c}\text { Length } \\
(\mathrm{mm})\end{array}$ & $\begin{array}{l}\text { Width } \\
(\mathrm{mm})\end{array}$ & $\begin{array}{c}\text { Area } \\
\left(\mathrm{mm}^{2}\right)\end{array}$ \\
\hline GA 11002 & 0.76 & 2.39 & 0.57 & 1.25 \\
\hline GA 11003 & 1.14 & 2.63 & 0.76 & 1.66 \\
\hline GA 11004 & 1.51 & 2.75 & 0.95 & 2.25 \\
\hline ADIA 11002 & 0.76 & 2.75 & 0.77 & 1.94 \\
\hline ADIA 11003 & 1.14 & 2.90 & 0.79 & 2.17 \\
\hline ADIA 11004 & 1.51 & 3.17 & 0.88 & 2.57 \\
\hline AIXR 11002 & 0.76 & 2.40 & 0.57 & 1.23 \\
\hline AIXR 11003 & 1.14 & 2.82 & 0.67 & 1.68 \\
\hline AIXR 11004 & 1.51 & 3.12 & 0.86 & 2.21 \\
\hline
\end{tabular}

Table 2 summarizes the analysis of variance of the parameters studied. The triple interactions were not significant; however, at least one double interaction was significant for each parameter. Thus, the means were then compared. 
TABLE 2. Summary of the table of variance analysis of data for $\mathrm{Dv}_{0.1}, \mathrm{Dv}_{0.5}, \mathrm{Dv}_{0.9}$, relative amplitude (RA) and droplet speed, resulting for three air induction spray nozzle models, at different flow rates and working pressures.

\begin{tabular}{cccccc}
\hline \multirow{2}{*}{ Source of variation } & \multicolumn{5}{c}{ Value of F calculated } \\
\cline { 2 - 5 } & $\mathrm{Dv}_{0.1}$ & $\mathrm{Dv}_{0.5}$ & $\mathrm{Dv}_{0.9}$ & $\mathrm{RA}$ & Speed \\
\hline Model & $149.771^{*}$ & $348.833^{*}$ & $377.042^{*}$ & $109.802^{*}$ & $0.377^{\mathrm{ns}}$ \\
Flow & $15.856^{*}$ & $14.549^{*}$ & $36.232^{*}$ & $64.325^{*}$ & $182.151^{*}$ \\
Pressure & $109.633^{*}$ & $337.999^{*}$ & $732.391^{*}$ & $323.187^{*}$ & $44.349^{*}$ \\
Model $\times$ Flow & $7.787^{*}$ & $18.781^{*}$ & $19.685^{*}$ & $5.294^{*}$ & $11.254^{*}$ \\
Model $\times$ Pressure & $17.168^{*}$ & $41.934^{*}$ & $26.710^{*}$ & $44.830^{*}$ & $1.435^{\mathrm{ns}}$ \\
Flow $\times$ Pressure & $0.414^{\mathrm{ns}}$ & $4.947^{*}$ & $10.457^{*}$ & $16.214^{*}$ & $1.940^{\mathrm{ns}}$ \\
Model $\times$ Flow $\times$ Pressure & $0.786^{\mathrm{ns}}$ & $0.774^{\mathrm{ns}}$ & $0.661^{\mathrm{ns}}$ & $0.906^{\mathrm{ns}}$ & $0.223^{\mathrm{ns}}$ \\
\hline C.V. $(\%)$ & 10.03 & 10.56 & 8.31 & 4.79 & 7.05 \\
\hline
\end{tabular}

C.V.: Coefficient of variation; * significant at $0.05 ;{ }^{\text {ns }}$ non-significant at 0.05 .

The three spray nozzle models showed differences in $\mathrm{Dv}_{0.1}$ (Table 3). The ADIA presented the highest values while the AIXR presented the lowest, although in some situations it did not differ from the GA. The nominal flow rate also promoted differences in the GA and ADIA, but there was no distinction with AIXR. The flow rate of $0.76 \mathrm{Lmin}^{-1}$ promoted higher $\mathrm{Dv}_{0.1}$ than the flow rate of $1.14 \mathrm{~L} \mathrm{~min}^{-1}$. Regarding the effect of pressure, its increase reduced $\mathrm{Dv}_{0.1}$.

TABLE 3. Average diameters of accumulated volumes of $10 \%\left(\mathrm{Dv}_{0.1}\right)$ resulting from applications with three spray nozzle models with air induction as a function of flow rate and working pressure.

\begin{tabular}{cccc}
\hline & \multicolumn{3}{c}{$\operatorname{Dv}_{0.1}(\mu \mathrm{m})$} \\
\cline { 2 - 4 } Flow $\left(\mathrm{L} \mathrm{min}^{-1}\right)$ & $\mathrm{GA}$ & Nozzle model & AIXR \\
\hline 0.76 & $117.50 \mathrm{bA}$ & $156.87 \mathrm{aA}$ & $103.40 \mathrm{cA}$ \\
1.14 & $97.18 \mathrm{bB}$ & $138.88 \mathrm{aB}$ & $102.20 \mathrm{bA}$ \\
1.51 & $114.28 \mathrm{bA}$ & $131.52 \mathrm{aB}$ & $99.54 \mathrm{cA}$ \\
\hline \multirow{2}{*}{ Pressure $(\mathrm{kPa})$} & $\mathrm{GA}$ & Nozzle model \\
& $123.08 \mathrm{bA}$ & ADIA & AIXR \\
\hline 200 & $107.01 \mathrm{bB}$ & $177.34 \mathrm{aA}$ & $111.68 \mathrm{cA}$ \\
300 & $98.86 \mathrm{bB}$ & $138.04 \mathrm{aB}$ & $102.35 \mathrm{bA}$ \\
400 & $111.90 \mathrm{aC}$ & $91.11 \mathrm{bB}$ \\
\hline
\end{tabular}

Averages followed by different letters, lower case in the line and upper case in the column, differ from each other by Tukey's test, at a level of 0.05 of significance.

The $\mathrm{Dv}_{0.1}$ characteristic is important in droplet spectrum evaluations. The higher this value is, the lower the potential risk of drift (Camara et al., 2008). In this sense, it is possible to note that the ADIA had the highest potential for drift reduction, since its $\mathrm{Dv}_{0.1}$ was up to $52 \%$ higher than the others, depending on the operational condition considered. For example, the ADIA 11002 nozzle generated an average $\mathrm{Dv}_{0.1}$ of $157 \mu \mathrm{m}$ which means that $10 \%$ of the volume sprayed is in drops smaller than or equal to that value. In contrast, the AIXR 11002 generated an average $\mathrm{Dv}_{0.1}$ of $103 \mu \mathrm{m}$, denoting greater risk of drift.

Air induction nozzles can also produce droplets with drift potential under different flow conditions and working pressures. These results indicate the scale of the challenge in the field to minimize the impact of adverse weather conditions on the droplets. Although air induction aims to reduce drift by increasing the droplet size, the nozzles do not all produce droplets of the same size. Thus, even with the increase in mean values, such as in $\mathrm{Dv}_{0.5}$, there is the production of fine droplets, especially when there is heterogeneity in the spectrum. Hence the need to pay attention to the characteristics of the nozzles, even when using those with anti-drift potential. Piggott \& Matthews (1999) warned about the need to consider best practices, even when using air- induction nozzles.

$\mathrm{Dv}_{0.5}$, also known as the volume median diameter, is the parameter that is most commonly used to characterize the spectrum of droplets from a spray nozzle. Although all the nozzles evaluated had the Venturi system, the results showed that their behavior is different (Table 4). The ADIA presented the highest values, followed by GA, and then the AIXR. Using the 11002, 11003, and 11004 tips $(0.76,1.14$, and $\left.1.51 \mathrm{~L} \mathrm{~min}^{-1}\right)$, the difference between ADIA and AIXR was $82.8 \%, 69.7 \%$, and $56.1 \%$, respectively, which demonstrates that the nozzle design has a strong influence on the spectrum of generated droplets. Analyzing Table 1, it can be seen that the ADIA had the largest areas of the exit hole, justifying the result presented. 
TABLE 4. Average diameters of 50\% accumulated volumes $\left(\mathrm{Dv}_{0.5}\right)$ resulting from applications with three spray nozzle models with air induction as a function of flow rate and working pressure.

\begin{tabular}{cccc}
\hline & \multicolumn{3}{c}{ Dv $_{0.5}(\mu \mathrm{m})$} \\
\cline { 2 - 4 } Flow $\left(\mathrm{L} \mathrm{min}^{-1}\right)$ & $\mathrm{GA}$ & Nozzle model & AIXR \\
\hline 0.76 & $236.53 \mathrm{bA}$ & $388.11 \mathrm{aA}$ & $212.27 \mathrm{cA}$ \\
1.14 & $198.35 \mathrm{bB}$ & $352.64 \mathrm{aB}$ & $207.78 \mathrm{bA}$ \\
1.51 & $253.21 \mathrm{bA}$ & $304.39 \mathrm{aC}$ & $195.00 \mathrm{cA}$ \\
\hline \multirow{2}{*}{ Pressure $(\mathrm{kPa})$} & $\mathrm{GA}$ & Nozzle model & AIXR \\
\hline 200 & $291.67 \mathrm{bA}$ & ADIA & $253.81 \mathrm{cA}$ \\
300 & $212.60 \mathrm{bB}$ & $482.73 \mathrm{aA}$ & $191.76 \mathrm{bB}$ \\
400 & $183.82 \mathrm{bC}$ & $333.95 \mathrm{aB}$ & $169.48 \mathrm{bB}$ \\
\hline \multirow{2}{*}{ Pressure $(\mathrm{kPa})$} & 0.76 & $228.46 \mathrm{aC}$ & 1.51 \\
\hline 200 & $346.96 \mathrm{abA}$ & Flow $\left(\mathrm{L} \mathrm{min}{ }^{-1}\right)$ & $353.22 \mathrm{aA}$ \\
300 & $270.48 \mathrm{aB}$ & $328.02 \mathrm{bA}$ & $224.25 \mathrm{bB}$ \\
400 & $219.46 \mathrm{aC}$ & $243.58 \mathrm{bB}$ & $175.13 \mathrm{bC}$ \\
\hline
\end{tabular}

Averages followed by different letters, lower case in the line and upper case in the column, differ from each other by Tukey's test, at a level of 0.05 of significance.

The air induction nozzles are configured as long fluid chambers with small holes connected to the outside. These orifices induce air into the liquid due to the Venturi effect, which reduces the pressure in the outlet orifice and increases the size of the droplets. However, Butler-Ellis et al. (2002) stated that the size of the droplets is more affected by the size of the final orifice than by the air intake. In this sense, air induction nozzles tend to have larger outlet holes compared to non- induction, which also helps explain the difference in droplet size (Guler et al., 2007).

Regarding the influence of the nominal flow, no clear trend was noticed. While for the AIXR tip, the flow did not interfere with the $\mathrm{Dv}_{0.5}$, the increase in flow promoted the reduction of nominal flow in the ADIA. With the GA, the flow rate of $1.14 \mathrm{~L} \mathrm{~min}^{-1}$ resulted in lower $\mathrm{Dv}_{0.5}$ compared to the other flow rates. When analyzing the interaction pressure versus flow, it is noted that in the two highest pressures, the increase in flow reduced the $\mathrm{Dv}_{0.5}$. At the lower pressure, the effect was the opposite. Piggott \& Matthews (1999) stated that the nozzles with air induction working at pressures close to $200 \mathrm{kPa}$ present a large variation in the spray pattern, which may help to explain the results obtained.

Available literature in general relates the increase in the nominal flow of the nozzle to an increase in the size of the droplets (Nuyttens et al., 2007). However, this trend was not observed in this study. Again, it should be noted that the air induction nozzles have a very characteristic operation, which differentiates them from the others, given the presence of the turbulence chamber where the mixing of air and liquid occurs.

Viana et al. (2010) found that a lower nominal flow caused greater dispersion of the liquid into droplets. However, the increase in flow can be obtained by increasing the length of the oblong hole of the liquid outlet without a corresponding increase in width, which could lead to a reduction in the size of the droplets. In this sense, the shape of the outlet hole can help explain this behavior, as shown in Table 1. The ADIA, for example, obtained a more pronounced increase in the length of the orifice by increasing the nominal flow, resulting in a reduction of $\mathrm{Dv}_{0.5}$. The AIXR and GA presented a greater amplitude of variation in width as a function of the flow increase.

With regard to the effect of pressure, what was expected has occurred: the increase in pressure has promoted a reduction in the size of the droplets. Nuyttens et al. (2007) also verified this relationship between pressure and droplet size. However, the authors warned that the magnitude of the changes is dependent on the nozzle type and can be more or less pronounced, which demonstrates the need to study the relationship in different situations.

According to Mandato et al. (2012), the increase in pressure is converted into kinetic energy, accelerating the speed of the liquid in relation to the ambient air. The increase in velocity leads to an increase in the level of turbulence in the liquid blade and in the aerodynamic drag forces exerted by the surrounding air, which promotes the disintegration of the liquid jet into smaller droplets. However, this process is dependent on the geometry of the nozzle, especially those using the Venturi principle (Piggott \& Matthews, 1999).

In the interactions between the flow and model and pressure and model, the GA and AIXR produced $\mathrm{Dv}_{0.5}$ lower or close to $250 \mu \mathrm{m}$ under certain operational conditions. In general, $\mathrm{Dv}_{0.5}$ values below $250 \mu \mathrm{m}$ indicate the potential risk of drift, which occurs mainly due to droplets smaller than 150 $\mu \mathrm{m}$. On the other hand, $\mathrm{Dv}_{0.5}$ values above $500 \mu \mathrm{m}$ suggest runoff problems, which commonly occur with droplets larger than $800 \mu \mathrm{m}$ (Cunha et al., 2003).

In relation to $\mathrm{Dv}_{0.9}$, the behavior was similar to $\mathrm{Dv}_{0.5}$ (Table 5). The highest values were generated by the ADIA and the lowest, with the AIXR. The increase in pressure resulted in the decrease of $\mathrm{Dv}_{0.9}$ for the three models. The increase of the flow also resulted in the decrease of $\mathrm{Dv}_{0.9}$ for the ADIA and AIXR. However, there was no clear relation for the GA tip. Analyzing the interaction flow versus pressure, it is noted that the change in flow did not promote differences in the pressure of $200 \mathrm{kPa}$, but it did so at pressures of 300 and $400 \mathrm{kPa}$, presenting an inverse relationship. 
TABLE 5. Average diameters of $90 \%$ accumulated volumes $\left(\mathrm{Dv}_{0.9}\right)$ for applications with three spray nozzle models with air induction as a function of the flow rate and working pressure.

\begin{tabular}{|c|c|c|c|}
\hline \multirow{3}{*}{ Flow $\left(\mathrm{L} \mathrm{min}{ }^{-1}\right)$} & \multicolumn{3}{|c|}{$\mathrm{Dv}_{0.9}(\mu \mathrm{m})$} \\
\hline & \multicolumn{3}{|c|}{ Nozzle model } \\
\hline & GA & ADIA & AIXR \\
\hline 0.76 & $482.34 \mathrm{bA}$ & $676.75 \mathrm{aA}$ & $407.48 \mathrm{cA}$ \\
\hline 1.14 & $418.00 \mathrm{bB}$ & $624.07 \mathrm{aB}$ & $394.94 \mathrm{bA}$ \\
\hline 1.51 & $481.02 \mathrm{bA}$ & $529.88 \mathrm{aC}$ & $340.69 \mathrm{bB}$ \\
\hline \multirow{2}{*}{ Pressure $(\mathrm{kPa})$} & \multicolumn{3}{|c|}{ Nozzle model } \\
\hline & GA & ADIA & AIXR \\
\hline 200 & $609.81 \mathrm{bA}$ & $840.70 \mathrm{aA}$ & $522.34 \mathrm{cA}$ \\
\hline 300 & $437.65 \mathrm{bB}$ & $591.63 \mathrm{aB}$ & $343.87 \mathrm{cB}$ \\
\hline 400 & $333.90 \mathrm{bC}$ & $398.37 \mathrm{aC}$ & $276.89 \mathrm{cC}$ \\
\hline \multirow{2}{*}{ Pressure $(\mathrm{kPa})$} & \multicolumn{3}{|c|}{ Flow $\left(\mathrm{L} \min ^{-1}\right)$} \\
\hline & 0.76 & 1.14 & 1.51 \\
\hline 200 & $659.75 \mathrm{aA}$ & $651.50 \mathrm{aA}$ & $661.61 \mathrm{aA}$ \\
\hline 300 & $511.09 \mathrm{aB}$ & $465.22 \mathrm{bB}$ & $396.84 \mathrm{cB}$ \\
\hline 400 & $395.72 \mathrm{aC}$ & $320.29 \mathrm{bC}$ & $293.14 \mathrm{bC}$ \\
\hline
\end{tabular}

Averages followed by different letters, lower case in the line and upper case in the column, differ from each other by Tukey's test, at a level of 0.05 of significance.

The $\mathrm{Dv}_{0.9}$ indicates that $90 \%$ of the volume sprayed is in droplets smaller (or, $10 \%$ of the volume sprayed is in droplets larger) than this value. If the $\mathrm{Dv}_{0.9}$ is large, much of the volume may be contained in a few large droplets. In this case, the coverage and effectiveness of the application may be reduced by not having enough droplets to adequately cover the entire treated surface. In this sense, it should be noted that pressure has a strong influence on this parameter and, therefore, when greater coverage of the target is required as in the case of contact phytosanitary products, pressures above $300 \mathrm{kPa}$ should be prioritized. In the case of the ADIA, for example, by increasing the pressure from 200 to $300 \mathrm{kPa}$, a reduction from 841 to $592 \mu \mathrm{m}$ is achieved in the average of the three nominal flows.

The RA is a parameter that helps to determine the homogeneity of the size of droplets. In all flows, the ADIA and AIXR stood out, showing greater uniformity of the droplets (Table 6). This behavior also occurred when analyzing the interaction pressure for different models, with the exception of the behavior corresponding to the pressure of $400 \mathrm{kPa}$, where the GA was equal to the ADIA.

TABLE 6. Relative Amplitude (RA) resulting from applications of three models of air induction spray nozzles as a function of flow rate and working pressure.

\begin{tabular}{|c|c|c|c|}
\hline \multirow{3}{*}{ Flow $\left(\mathrm{L} \mathrm{min}^{-1}\right)$} & \multicolumn{3}{|c|}{ RA } \\
\hline & \multicolumn{3}{|c|}{ Nozzle model } \\
\hline & GA & ADIA & AIXR \\
\hline 0.76 & $1.53 \mathrm{aA}$ & $1.34 \mathrm{cA}$ & $1.40 \mathrm{bA}$ \\
\hline 1.14 & $1.58 \mathrm{aA}$ & $1.35 \mathrm{bA}$ & $1.36 \mathrm{bA}$ \\
\hline 1.51 & $1.39 \mathrm{aB}$ & $1.27 \mathrm{bB}$ & $1.20 \mathrm{cB}$ \\
\hline \multirow{2}{*}{ Pressure $(\mathrm{kPa})$} & \multicolumn{3}{|c|}{ Nozzle model } \\
\hline & GA & ADIA & AIXR \\
\hline 200 & $1.68 \mathrm{aA}$ & $1.37 \mathrm{cA}$ & $1.61 \mathrm{bA}$ \\
\hline 300 & $1.56 \mathrm{aB}$ & $1.35 \mathrm{bA}$ & $1.25 \mathrm{cB}$ \\
\hline 400 & $1.27 \mathrm{aC}$ & $1.24 \mathrm{aB}$ & $1.09 \mathrm{bC}$ \\
\hline \multirow{2}{*}{ Pressure $(\mathrm{kPa})$} & \multicolumn{3}{|c|}{ Flow $\left(\mathrm{L} \min ^{-1}\right)$} \\
\hline & 0.76 & 1.14 & 1.51 \\
\hline 200 & $1.52 \mathrm{bA}$ & $1.65 \mathrm{aA}$ & $1.50 \mathrm{bA}$ \\
\hline 300 & $1.45 \mathrm{aB}$ & $1.46 \mathrm{aB}$ & $1.26 \mathrm{bB}$ \\
\hline 400 & $1.30 \mathrm{aC}$ & $1.18 \mathrm{bC}$ & $1.11 \mathrm{cC}$ \\
\hline
\end{tabular}

Averages followed by different letters, lower case in the line and upper case in the column, differ from each other by Tukey's test, at a level of 0.05 of significance. 
For the three nozzle models, with the increase in flow there was an increase in the uniformity of the drops, which also occurred with the increase in pressure. Again, analyzing the interaction flow versus pressure, there was no clear trend in relation to the change in flow. The increase in pressure promoted an increase in RA.

As the quality of the spray increased, more demands should be made on the performance of the nozzles and especially on the homogeneity of the droplet spectrum. Numerically, the higher the value of the RA, the larger the size range of the droplets sprayed (Cunha et al., 2016). The homogeneous droplet spectrum has a value of relative amplitude tending to zero. The values of $\mathrm{Dv}_{0.5}$ and RA should be analyzed together for the characterization of the spray. $\mathrm{Dv}_{0.5}$ alone provides a reference value, without indicating data dispersion around this value (Cunha et al., 2003; McGinty et al., 2019). It should also be noted that the spectrum of droplets may be influenced by the physicochemical characteristics of the spray solution. Changes in viscosity or surface tension, for example, interfere with the process of hydraulic spraying and may change the size of the droplets.

Regarding the speed of the droplets (Tables 7 and 8), the behavior of the three models was influenced by the flow of the nozzle. In the lower flow, the GA promoted a lower speed compared to the others. For the flow rate of $1.14 \mathrm{~L}$ $\mathrm{min}^{-1}$, the GA and ADIA promoted similar speeds. For the higher flow, the ADIA generated the lowest speed in relation to the others. The point to highlight is that the evaluations were made at a distance of $0.5 \mathrm{~m}$ from the nozzle considering the average of the entire spectrum, which suggests that the measured speeds are close to the terminal velocity of the droplets, reducing the effect of the nozzle due to the resistance promoted by ambient air.

TABLE 7. Droplet speed resulting from applications with three models of air induction spray nozzles as a function of nominal flow rate.

\begin{tabular}{cccc}
\hline & \multicolumn{3}{c}{ Speed $\left(\mathrm{m} \mathrm{s}^{-1}\right)$} \\
\cline { 2 - 4 } Flow $\left(\mathrm{L}\right.$ min $\left.^{-1}\right)$ & GA & Nozzle model & AIXR \\
\hline 0.76 & $1.94 \mathrm{bC}$ & $2.18 \mathrm{aC}$ & $2.17 \mathrm{aC}$ \\
1.14 & $2.55 \mathrm{aB}$ & $2.46 \mathrm{abB}$ & $2.35 \mathrm{bB}$ \\
1.51 & $2.88 \mathrm{aA}$ & $2.64 \mathrm{bA}$ & $2.85 \mathrm{aA}$ \\
\hline
\end{tabular}

Averages followed by different letters, lower case in the line and upper case in the column, differ from each other by Tukey's test, at a level of 0.05 of significance.

TABLE 8. Droplet speed resulting from applications at three working pressures.

\begin{tabular}{cc}
\hline Pressure $(\mathrm{kPa})$ & Speed $\left(\mathrm{m} \mathrm{s}^{-1}\right)$ \\
\hline 200 & $2.26 \mathrm{C}$ \\
300 & $2.49 \mathrm{~B}$ \\
400 & $2.59 \mathrm{~A}$ \\
\hline
\end{tabular}

Averages followed by different letters differ by Tukey's test, at a level of 0.05 of significance.

Nuyttens et al. (2009) stated that the speed of droplets is linked to their size, and larger diameters result in higher speeds. However, this relationship was not always observed in the present study, because the flow itself interfered in the process, preventing a generalization. The speed is not only linked to the size of the droplets but also to the kinetic energy of the droplet during launching. The turbulence generated internally at the air induction nozzle may also have contributed to the presented result (Etheridge et al., 1999).

Regarding the effect of pressure on the speed of droplets, there was no interaction with the models and flows. Higher pressures always generated higher droplet speeds. The increase in pressure increases the kinetic energy of the droplets, resulting in increased velocity. Higher velocities cause the droplets to traverse the path between the droplet launch and the target in less time, contributing to the reduction of drift (França et al., 2018).

The magnitude of the variation in the speed of the droplets was not very high. This was probably due to the fact that the average speed for the entire spectrum was considered. Characterization according to the different size ranges in the population of the droplets could result in greater discrepancies in the speed and find the relationship between droplet size and speed. Nuyttens et al. (2009) evaluated the droplet speed from a standard 11003 flat fan nozzle considering different droplet size ranges. The authors found speeds ranging from 1 to $9 \mathrm{~m} \mathrm{~s}^{-1}$, depending on the working pressure. Wang et al. (2015) also found higher speeds while evaluating different spray nozzles. The authors attribute these higher values to the fact that they made the measurements closest to the spray nozzle, which also interferes with the speed values of the droplets.

\section{CONCLUSIONS}

The geometry of the air induction spray nozzle model interfered with the spectrum and the droplet speed. The ADIA promoted $\mathrm{Dv}_{0.5}$ (VMD) superior to AIXR and GA, reaching differences of up to $90 \%$, depending on the operating condition.

The increase in work pressure promoted a reduction in the size of the droplets regardless of the nozzle model used; however, there was no defined behavior for the relationship between nominal flow and droplet size.

The ADIA and AIXR nozzles showed greater uniformity of the droplets in most of the assessed conditions.

The increase in pressure promoted an increase in the speed of the droplets. However, the effect of the nozzle model on this parameter was dependent on the nominal flow rate. 


\section{ACKNOWLEDGEMENTS}

The authors would like to thank FAPEMIG (Research Foundation of the State of Minas Gerais), CNPq (National Council of Scientific and Technological Development) and CAPES (Coordination for the Improvement of Higher Education Personnel) for the financial support.

\section{REFERENCES}

Butler-Ellis MC, Swan T, Miller PCH, Waddelow S, Bradley A, Tuck CR (2002) Design factors affecting spray characteristics and drift performance of air induction nozzles. Biosystems Engineering 82(3):289-296. DOI: https://doi.org/10.1006/bioe.2002.0069

Butts TR, Butts LE, Luck JD, Fritz BK, Hoffmann WC, Kruger GR (2019a) Droplet size and nozzle tip pressure from a pulse-width modulation sprayer. Biosystems Engineering 178(2):52-69. DOI: https://doi.org/10.1016/j.biosystemseng.2018.11.004

Butts TR, Luck JD, Fritz BK, Hoffmann WC, Kruger GR (2019b) Evaluation of spray pattern uniformity using three unique analyses as impacted by nozzle, pressure, and pulsewidth modulation duty cycle. Pest Management Science 75:1875-1886. DOI: https://doi.org/10.1002/ps.5352

Bueno MR, Cunha JPAR, Santana DG (2017) Assessment of spray drift from pesticide applications in soybean crops. Biosystems Engineering 154:35-45. DOI: https:// doi.org/10.1016/j.biosystemseng.2016.10.017

Camara FT, Santos JL, Silva EA, Ferreira MC (2008) Distribuição volumétrica e espectro de gotas de bicos hidráulicos de jato plano de faixa expandida XR 11003. Engenharia Agrícola 28(4):740-749. DOI: https://doi.org/10.1590/S0100-69162008000400014

Carvalho FK, Antuniassi UR, Chechetto RG, Mota AAB, Jesus MG de, Carvalho LR de (2017) Viscosity, surface tension and droplet size of sprays of different formulations. Crop Protection 101:19-23. DOI: https://doi.org/10.1016/j.cropro.2017.07.014

Cunha JPAR, Teixeira MM, Coury JR, Ferreira LR (2003) Avaliação de estratégias para redução da deriva de agrotóxicos em pulverizações hidráulicas. Planta Daninha 21(2):325-332. DOI: https://doi.org/10.1590/S010083582003000200019

Cunha JPAR, Marques RS, Alves GS (2016) Deposição da calda na cultura da soja em função de diferentes pressões de trabalho e pontas de pulverização. Revista Ceres 63(6):761768. DOI: https:// doi.org/10.1590/0034-737x201663060003

Etheridge RE, Womac AR, Mueller TC (1999)

Characterization of the spray droplet spectra and patterns of four venturi-type drift reduction nozzles. Weed Technology 13(4):765-770. DOI:

https://doi.org/10.1017/S0890037X00042202

Ferguson JC, Chechetto RG, Hewitt AJ, Chauhan BS, Adkins SW, Kruger GR, O'Donnell CC (2016) Assessing the deposition and canopy penetration of nozzles with different spray qualities in an oat (Avena sativa L.) canopy. Crop Protection 81:14-19. DOI: https:// doi.org/10.1016/j.cropro.2015.11.013
Ferguson JC, O'Donnell CC, Chauhan BS, Adkins SW, Kruger GR, Wang R, Ferreira PHU, Hewitt AJ (2015) Determining the uniformity and consistency of droplet size across spray drift reducing nozzles in a wind tunnel. Crop Protection 76:1-6. DOI:

https://doi.org/10.1016/j.cropro.2015.06.008

França JAL, Cunha JPAR, Antuniassi UR (2018) Spectrum and velocity of droplets of spray nozzles with and without air induction. Engenharia Agrícola 38(2):232237. DOI: http:// dx.doi.org/10.1590/1809-4430Eng.Agric.v38n2p232-237/2018

Garcerá C, Román C, Moltó E, Abad R, Insa JA, Torrent X, Planas S, Chueca P (2017) Comparison between standard and drift reducing nozzles for pesticide application in citrus: Part II. Effects on canopy spray distribution, control efficacy of Aonidiella aurantii (Maskell), beneficial parasitoids and pesticide residues on fruit. Crop Protection 94:83-96. DOI: https:// doi.org/10.1016/j.cropro.2016.12.016

Guler H, Zhu H, Ozkan HE, Derksen RC, Yu Y, Krause CR (2007) Spray characteristics and drift reduction potential with air induction and conventional flat-fan nozzles. Transactions of the ASABE 50(3):745-754. DOI: https://doi.org/10.13031/2013.23129

Mandato S, Rondet E, Delaplace G, Barkouti A, Galet L, Accart P, Ruiz T, Cuq B (2012) Liquids' atomization with two different nozzles: Modeling of the effects of some processing and formulation conditions by dimensional analysis. Powder Technology 224:323-330. DOI: https:// doi.org/10.1016/j.powtec.2012.03.014

McGinty JA, Morgan GD, Dotray PA, Baumann PA (2019) Herbicide formulation, spray nozzle design, and operating pressure affects the droplet size spectra of agricultural sprays. Journal of Experimental Agriculture International 38(3):1-7. DOI: https:// doi.org/10.9734/JEAI/2019/v38i330304

Nuyttens D, De Schampheleire M, Verboven P, Brusselman E, Dekeyser D (2009) Droplet size and velocity characteristics of agricultural sprays. Transactions of the Asabe 52(5):1471-1480.

Nuyttens D, Baetens K, De Schampheleire M, Sonck B (2007) Effect of nozzle type, size and pressure on spray droplet characteristics. Biosystems Engineering 97(3):333e345. DOI: https:// doi.org/10.1016/j.biosystemseng.2007.03.001

Piggott SJ, Matthews GA (1999) Air induction nozzles: a solution to spray drift? International Pest Control 41:24-28.

Viana RG, Ferreira LR, Ferreira MC, Teixeira MM, Rosell JR, Santos LDT, Machado AFL (2010) Distribuição volumétrica e espectro de gotas de pontas de pulverização de baixa deriva. Planta Daninha 28(2):439-446. DOI: https://doi.org/10.1590/S0100-83582010000200024

Wang S, Dorr GJ, Khashehchi M, He X (2015) Performance of selected agricultural spray nozzles using particle image velocimetry. Journal of Agricultural Science and Technology 17:601-613. 